\section{Tone Kvernbekk}

Evidence-based Practice in Education.

Functions of evidence and causal presuppositions.

New York: Routledge, 2016

Lige siden David Hargreaves i 1996 afholdt sin omdiskuterede Teacher Training Agency (TTA) forelæsning, hvor han opfordrede til, at uddannelsessystemet burde indrettes med den evidensbaserede medicin som forbillede, har der internationalt eksisteret en intens debat om evidensforskningens og i særdeleshed randomiserede kontrollerede forsøgs (RCT) rolle i pædagogik og uddannelse. Også i Danmark har debatten været og er fortsat intens. Selv om tanken og udførelsen af evidensbaseret forskning stadig vinder indpas, eksisterer der fortsat en strid om, hvilken rolle evidensforskning har i pædagogik og uddannelse, og om den overhovedet har eller burde have en?

Den norske professor i videnskabsfilosofi og pædagogisk filosofi Tone Kvernbekk har med bogen "Evidence-based Practice in Education: Functions of evidence and causal presuppositions" bidraget til debatten om evidensens rolle og funktion $\mathrm{i}$ en evidensbaseret praksis (EBP) og $\mathrm{i}$ uddannelsesfeltet generelt. Kvernbekk formår, via sin avancerede forståelse for et ofte udskældt kausalitetsbegreb, nøgternt at skrive sig ind mellem to betændte polariseringer i pædagogikken. På den ene side dem, som hilser evidensen velkommen på grund af dens evne til at belyse simple, regelmæssige (kausale) sammenhænge, repræsenteret af blandt andre David Hargreaves, ${ }^{1}$ og på den anden side de, der ikke accepterer kausaliteten i pædagogikken, da de mener og definerer kausalitet ud fra, at mennesker ikke besidder samme (kausal)strukturer som fysiske objekter, repræsenteret af blandt andre Gert Biesta. ${ }^{2}$ Igennem sin brug af en videnskabsteoretisk realismeorienteret systemteori, der skelner mellem åbne og lukkede systemer og et pluralistisk kausalitetsbegreb, fremskriver Kvernbekk mulighederne for at skabe en mellemvej mellem disse to polariseringer. Kvernbekks videnskabsteoretiske realisme tillader hende på fin vis at fremvise, hvorledes evidens og kausalitet i pædagogik og uddannelse ikke behøver at være et enten-eller, men i stedet kan og bør være et både-og. Som Kvernbekk skriver, så er hun "a critical friend to EBP", 3 selvom jeg tænker,

1 David Hargreaves, "Teaching as a research-based profession: Possibilities and prospects," The Teacher Training Agency Annual Lecture 1996, (1996): 5.

2 Gert Biesta,"Why “"What Works” Won't Work: Evidene-based Practice and the Democratic Deficit in Educational Research", Educational Theory 57, no. 1 (2007): 8-10.

3 Tone Kvernbekk, Evidence-based Practice in Education (New York: Routledge, 2016), 3. at mange evidensfortalere mest vil opfatte Kvernbekk som "kritisk" og mindre som ven.

Ved at åbne for en realismeorienteret systemteori og et probabilistisk, pluralistisk kausalitetsbegreb - primært hentet med inspiration fra den engelske kausalteoretiker og filosof Nancy Cartwright - opnår Kvernbekk, for mig at se, tre afgørende mål i bogen:

For det første formår Kvernbekk at sætte videnskabelig viden på den rette plads, såvel i forhold til videnskabelig videns relation til politiske beslutninger som med hensyn til den videnskabelige videns forhold til pædagogisk praksis. Med hjælp fra Stephen Toulmins argumentationsmodel viser Kvernbekk overbevisende, hvordan videnskabelig viden ikke bør/kan fungere som det grundlæggende beslutningsgrundlag eller fundament for pædagogiske handlinger, men i stedet som en indirekte rygdækning (backing), der står ligeværdigt ved siden af praktikerens egne erfaringer. Dermed rykker Kvernbekk ved manges hidtidige forståelse for/af evidensens rolle i pædagogisk praksis, idet hun fjerner den som det primære datagrundlag (data) for praktikerens konklusioner (conclusions) og handlingsgrundlag. Populært sagt gør hun evidensens forhold til praksis indirekte. Kvernbekks brug af Toulmins argumentationsmodel er på mange måder gennemført, idet Kvernbekk med denne model formår at illustrere det komplekse forhold, der eksisterer mellem videnskabelig viden og pædagogisk praksis, hvortil Kvernbekk overbevisende viser, hvorledes garantier (warrants) om, hvad der virker, kræver stor forståelse for de kontekstuelle kvalifikationer/styrkemarkører (qualifiers) og indsigelser (rebuttals), der eksisterer i den givne kontekst. Dog er jeg i tvivl om, hvorvidt argumentationsteorien med sin vægt på logisk konsistens faktisk er den bedste til at beskrive den komplekse plurale empiriske og kausale verden, som Kvernbekk fremskriver i bogen. Med Pierre Bourdieus ord, hentet fra Karl Marx, tror jeg, at man skal passe på med at forveksle "the things of logic for the logic of things".

For det andet, og i forbindelse med ovenstående, formår Kvernbekk at stille RCT-forskningen og effektstørrelse-studier, som eksempelvis John Hatties, i et korrekt indirekte forhold til pædagogisk praksis. Kontroversielt, men overbevisende, lykkes det Kvernbekk at omvende læserens forståelsen af RCT-studiers generaliserbarhed og ekstern validitet. En blandt flere pointer som Kvernbekk henter fra Cartwrights kausalitetsfilosofi. Kvernbekk viser med sin pluralistiske kausalteori, modsat evidensfortalernes holdning hertil, at RCT kun giver en meget snæver kausalforståelse, idet RCT er udført i kon-

4 Pierre Bourdieu, "Men and Machines," in Advances in Social Theory and Methodology: Towards an Integration of Micro- and Macro-Sociologies, ed. K. KnorrCetina \& A.V. Cicourel (Boston: Routledge, 1981), 305. 
trollerede lukkede forhold/systemer med velafgrænsede kausalstrukturer, som yderst sjældent stemmer overens med de åbne forhold/ (endogene) systemer og kausalstrukturer som hverdagens pædagogiske kontekst udfolder sig i. Dermed formår Kvernbekk nøgternt at vise, at der er stor forskel på forholdet mellem, hvad der virkede der, og hvad der potentielt vil virke her. Kvernbekk fremstiller også det asymmetriske forhold, der eksisterer mellem at jagte årsager og anvende dem. Man bør give Kvernbekk stor cadeau for koncist og med hjælp fra Cartwright at illustrere, at forholdet mellem 'what worked' 'what works' og ' what will work' ikke blot handler om grammatiske petitesser;

Sidst, men ikke mindst, formår Kvernbekk at vise, hvorledes verden og mennesker sagtens kan fremstå som åbne (kontingente) og unikke, selvom forståelsen for kausalitet indføres i pædagogikken. Jeg vil overordnet argumentere for, at Kvernbekk med sit kausalitetsbegreb imødekommer begge de lejre, hun kritiserer. Hvorvidt hendes tilgang til evidens accepteres af disse to lejre er én ting, men hendes evne til at bygge bro henover disse er beundringsværdig.

Selvom Kvernbekk med sin realisme forsøger at bygge bro mellem to lejre, og selvom jeg både finder analyserne af kausalitet som kernen i EBP og analyserne af evidensteoretikeren John Hatties effektstørrelsesstudier adækvate - ud fra det ofte oversete faktum, at Hattie stedsvis skriver, at effektstørrelser "giver den bedste evidens til at føre til vigtige kausalforklaringer"s og "the fundamental word in meta-analysis, effect size, implies causation"6 - så er det åbenlyst, at Kvernbekk i en dansk sammenhæng vil møde modstand i forhold til at tilskrive Hattie og evidensforskningen en kausalitetsfortolkning. Dette skyldes, at der i en dansk kontekst har været en større kamp, fra blandt andre Niels Egelund og Lars Qvortrups side, ' for at vise, at Hatties studier ${ }^{8}$ og kvantitativ forskning generelt set ikke har noget med kausalitet at gøre. ${ }^{9}$ Man kan i en dansk kontekst muligvis tale om, at evidensbevægelsen

5 John Hattie, Synlig laering - for laerere (Frederikshavn: Dafolo, 2013), 300.

6 John Hattie, Visible Learning - A Synthesis of Over 800 Meta-analysis Relating to Achievement (New York: Routledge, 2009), 237.

7 Niels Egelund \& Lars Qvortrup, "For til den danske udgave" in Synlig laering - for larere, ed. John Hattie (Frederikshavn: Dafolo, 2013), 13.

8 Lars Qvortrup, "Baggrund for og diskussioner af Visible Learning med særligt henblik på lærings- og vidensbegrebet," Paideia 9 (2015), 25.

9 Lars Qvortrup, "Undervisning er udøvelse af professionel dømmekraft," in Evidens og dømmekraft. Når evidens møder den predagogiske praksis, ed. Claus Holm \& Hanne Balsby Thingholm (Frederikshavn: Dafolo, 2017), 163. eksisterer i en mere perpleks form, end dén Kvernbekk optegner i bogen, i og med at dele af den danske evidensbevægelse dels vil tillade RCT-studier, samtidig med, at de ikke ønsker at tale om kausalitet i pædagogikken. Jeg tillader mig dog alligevel at håbe, at den danske evidensbevægelse og dens kritikere tager Kvernbekks bidrag til efterretning. Det vil kunne (op)løse mange spændinger.

Bogen er fra evidenskritikernes side af blevet beskyldt for at repræsentere en simpel ontologisk model for kausalitet. ${ }^{10}$ Dog er det min bedste overbevisning, at denne beskyldning bygger på en forhastet og fejlagtig læsning af Kvernbekks pluralistiske kausalitetsbegreb, der samtidig ender med at levere et opgør med størstedelen af al hidtidig kausalitetsfilosofi. Kritikken misforstår, at pluralistisk kausalitet ikke blot handler om, at man har syn for flere faktorer end det monokausale forhold mellem $X$ og $Y$, men faktisk er åben over for og accepterer alle veldokumenterede kausalteorier, der afdækker forskelligartede empiriske fænomener, hvorfor Kvernbekks ontologiske model potentielt set også er åben over for og kan beskrive kritikernes ideer om, hvordan pædagogiske fænomener opfører sig kausalt. Kvernbekk argumenterer koncist for sit pluralistiske standpunkt ved at fremhæve at: "all causal theories have well-known counter-examples, a large number of different entities can serve as causal relata, and the causal relation is equally manifold. Thus, it stands to reason that EBP [evidence-based practice] should presuppose and employ different causal concepts and theories"11

At det er muligt og givetvis fair at anklage det pluralistiske udgangspunkt for at være abstrakt, ubeslutsomt og for rummeligt i retningen af 'everything goes', det kan jeg forstå, men simpelt er det næppe, tværtimod. Kritikken rammer kritikerne selv, idet de låser sig fast på, at den pædagogiske verden kun lader sig kausalt beskrive på én måde. Med deres monistiske kausalitetsteori begrænser kritikerne så at sige fænomenstrukturen i pædagogikken. Dette er for mig at se simpelt og en tænkningsmåde som Kvernbekks bidrag kan løsne op for. Uagtet ovenstående kritikpunkt, mener jeg stadig, at en af bogens vigtigste erkendelser er: "that the stability required for reliable reproduction of $Y$ resides mainly in the underlying causal system, not in the causal $X-Y$ relation itself".12

Kvernbekks kausalitetsteoretiske modeller skaber på alle måder gode muligheder for kritisk og konstruktivt at lade sig anvende i forhold til at analysere såvel de internationale som nordiske evidensbevægelser. Kvernbekks

10 Thomas Aastrup Rømer, "Pædagogik og kausalitet" in Uren paedagogik 3, ed. Thomas A. Rømer, Lene Tanggaard, Svend Brinkmann (Aarhus: Klim, 2017), 77.

11 Kvernbekk, Evidence-based Practice in Education, 178.

12 Kvernbekk, Evidence-based Practice in Education, 112. 
fremstilling af de forskellige kausalitetsteorier trækker oftest på fiktive og tænke eksempler på, hvordan de givne kausalteorier udfolder sig. Det kunne have været interessant og opløftende, hvis Kvernbekk havde benyttet lejligheden til at vise, hvordan de forskellige kausalitetsteorier arbejder empirisk i den pædagogiske forskning og praksis, som sideløber til Cartwright og Hardies ${ }^{13}$ illustrative empiriske eksempler. Hvis Kvernbekk havde gået mere empirisk til værks, tror jeg, Kvernbekk ville opdage, at det ikke er tilfældet, at den interventionistiske kausalitetsteori "is the theory that best elucidates the structure of EBP".14 Selvom dette er et beundringsværdigt ideal for evidensbevægelsen, fylder det utroligt lidt i den danske evidensbevægelse. ${ }^{15}$

I gennem hele bogen forsvarer Kvernbekk overordnet set evidenstanken og til dels evidensbevægelsen ipso facto, men med Kvernbekks begreber om åbne systemer, en ultra pluralistisk kausalitetsforståelse og begrebsliggøre af en ontologisk stærk kontingent verden, gør det, for mig at se, besværligt fuldstændigt at acceptere evidensbegrebets anatomi, så længe begrebet simpelt konnoterer til 'what works'-termen. I min læsning af Kvernbekk er jeg i tvivl om, hvor langt hun faktisk vil følge evidensbevægelsens nuværende diskurs, idet det kommer til at fremstå som om, at troen på, at forskningen kan oplyse om 'hvad der virker', i de fleste tilfælde og i særdeleshed på individniveau, vil ende med at levere falske profetier. Som Kvernbekk skriver: "Specific and detailed individual results are next to impossible to predict".16 Yderligere skriver Kvernbekk om den pædagogiske kontekst: "If the educational context changes or the students change, the proposed course of action might not work any more; and given the open, complex, and holistic nature of educational practice it seems more reasonable to assume that it will change".17 Med disse indsigelser mod fremtidige pædagogiske forudsigelser, bliver det for mig at se svært samtidig at acceptere den anvendelsesorienterede del af evidenstanken. I den forbindelse finder jeg også, at Kvernbekks forsvar for den nuværende 'what works"-tankegang og -diskurs, medfører, at Kvernbekk stedsvis retter en uberettiget kritik mod Biestas pointe om, at pædagogisk forskning maksimalt kan oplyse om, 'hvad der virkede' engang. Jeg finder, at Kvernbekk, i sin iver efter at kritisere Biesta, overser, at Biesta med denne

13 Nancy Cartwright \& Jeremy Hardie, Evidence-based Policy (Oxford: Oxford University Press, 2012).

14 Kvernbekk, Evidence-based Practice in Education, 74.

15 Mikkel Helding Vembye \& Hans Siggaard Jensen, "Hvorfor pædagogisk evidensforskning i sin nuværende form ikke er til megen hjælp", Nordic Studies in Education (indsendt).

16 Kvernbekk, Evidence-based Practice in Education, 117.

17 Kvernbekk, Evidence-based Practice in Education, 100. udtalelse faktisk deler den samme respekt for den probabilistiske, åbne og pluralistiske verdenen som Kvernbekk selv. Uagtet af dette, er jeg dog mestendels og overordnet enig i Kvernbekks kritiske stillingtagen til Biestas "kausal"filosofi.

I den mere nørdede afdeling fremstår det, for mig, som om Kvernbekk ikke fuldt ud formår præcist at fremlægge forholdet mellem Cartwrights strukturelle kausalligning, ${ }^{18}$ kausalkagemodel og John Mackies INUSbetingelser ${ }^{19}$ for kausalitet. Det fremstår uklart, om Kvernbekk mener, at det kun er ledet $b(i)(x)(i)$ i Cartwrights kausalligning, der repræsenterer Mackies INUSbetingelser, ${ }^{20}$ i så fald skal man huske på, at også leddene $z$ (i) og $u$ (i) ligeledes repræsenterer årsager, der fungerer som INUS-betingelser. Dette har for mig at se stor betydning for forståelsen af, hvor kompleks den pædagogiske verden de facto er.

Uafhængigt af ovenstående kritikpunkter leverer Kvernbekk i nordiske pædagogiske og filosofiske sammenhænge et savnet værk, som alternativ til de nuværende lejre i evidensdebatten. Jeg kan varmt anbefale bogen til alle med interesse for evidensdiskussionen. Kvernbekk leverer overordnet set en flot og præcis læsning af Nancy Cartwrights kausalfilosofi, som giver et åndehul i en ofte intens og kontrær evidensdebat. Kvernbekks pædagogiske formidlingsstil med en flydende progression og klare omend fiktive eksempler, som baggrund for bogens argumentation, gør det til en sand fornøjelse at læse.

Mikkel Helding Vembye,
Aarhus Universitet, Danmark
mihv@edu.au.dk

18 Cartwrights ligning: $y(i) c=a_{1}+a_{2} y_{0}(i)+a_{3} b(i) x(i)+a_{4} z(i)+u(i)$

19 INUS står for:"[a] cause is (..) an insufficient but necessary part of a condition which is itself unnecessary but sufficient for the result". Se John Mackie, "Causes and Conditions", American Philosophical Quarterly 4 (1965), 245.

20 Se Kvernbekk, Evidence-based Practice in Education, 136 for dette argument. 